\section{The periodic table of elements in chemistry textbooks for junior high-schools}

Marcin M. Chrzanowski, Irmina Buczek, Małgorzata Musialik, E. Barbara Ostrowska

DOI: $10.24131 / 3247.170109$

\section{Summary:}

The analysis of chemistry textbooks for the 3rd stage of education was carried out in order to obtain in-depth information on the degree of realization of the first educational goal from general requirements (learning outcomes) of the core curriculum: A student obtains and processes information from various sources with the use of information-communication technologies. The range of occurrence of content related to the periodic table of elements in chemistry textbooks for the 3rd stage of education was investigated. The choice of this source of information was dictated by the provisions of the curriculum for general education on the one hand, and on the other, by the fact that the periodic table is a foundation of modern chemistry - the good command of the periodic table not only allows to systematize the knowledge, but also, to anticipate and understand the properties of chemical elements. We analyzed all the series of chemistry textbooks for junior high schools,

received: 30.01.2017; accepted: 28.02.2017; published: 18.04 .2017

dr Marcin Chrzanowski: School Subject Teaching Department, Science Subjects Laboratory, Educational Research Institute in Warsaw., Biology Teaching Laboratory, Faculty of Biology, University of Warsaw

dr Małgorzata Musialik: School Subject Teaching Department, Science Subjects Laboratory, Educational Research Institute in Warsaw. which have been approved for use in schools by the Ministry of Education since 2009. The study results indicate that the content of all series of textbooks contains the periodic table of elements along with the materials helpful in forming the skills of reading data from such source of information. The most authors of textbooks also took care of that the periodic table of elements was present in every part of the series, which should help students in consolidating the ability to use this tool. The colors most often used in periodic tables to indicate the nature of the chemical elements were different shades of blue and pink, which may help in consolidating the knowledge, but it can also lead to the formation of students' misconceptions about the properties of elements.

Key words: core curriculum, textbook, periodic table of elements, Mendeleev's table, the 3rd stage of education (ISCED 2)

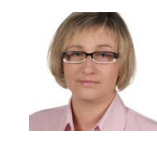

mgr Irmina Buczek: School Subject Teaching Department Science Subjects Laboratory, Educational Research Institute in Warsaw.

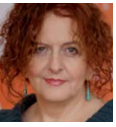

dr Elżbieta Barbara Ostrowska: School Subject Teaching Department, Science Subjects Laboratory, Education Research Institute in Warsaw.
Elements are not disparate entities but form interrelated fa milies (...). That we understand the origins of periodicity (...) means that we understand the personalities of the elements. Chemistry deals with entities that have personalities rather than their component parts, and it is right, I think, to present systematic as a story of the interaction of personalities

Atkins, 2005

\section{Introduction}

Pursuant to Regulation of the Minister of National Education of 23 December 2008 (MEN, 2008), implementation of the core curriculum of preschool and general education started in individual Polish school types beginning from the school year 2009/2010 (MEN, 2009). The provisions of the core curriculum are formulated as descriptions of results of the process of education as at the end of the specific level. They include knowledge and skills specific for each subject taught at school, listed as general and detailed requirements. It is worth stressing that they comply with the key competences mentioned in the Recommendations of the European Parliament of 18 December 2006 (Federowicz and Sitek, 2013).

As a consequence of implementation of the new core curriculum, textbooks were introduced taking provisions of that new curriculum into account. A textbook for general education should contain substantive and illustrative materials matching the presented teaching content, and make it possible for students with various abilities to acquire skills defined in the core curriculum of general education (Journal of Laws of 8 July 2014, item 909) (MEN, 2014).

The core curriculum for chemistry taught within the 3 rd level of education formulates three general objectives that describe the student's expected achievements in terms of skills required to master the subject. The first of them relates to the skill of acquiring and 
processing information from a variety of sources, the second one - to reasoning and application of acquired knowledge in practice, and the third one - to the mastering of practical skills in laboratory work. The teaching content (detailed objectives) are also stated as the student's expected achievements but pertain to individual skills described with operating verbs, as e.g.: the student describes, explains, enumerates, provides examples, uses etc. In the commentary to the core curriculum for chemistry, the following is mentioned among the basic sources of chemical information: tables, graphs, drawings, schemes and source texts. This publication is a fragment of the description of a literature-based analysis of chemistry textbooks for the 3rd level of education relating to the periodic table. The analysis was quantitative and at the same time qualitative (Pingel, 2009). Analyzed was the formulation in the textbooks of contents relating to the periodic table of the elements - the chemist's tool containing systematized knowledge about all chemical elements and their basic properties. The reading of information contained in table, as well as analysis and interpretation of such information, is among the major skills that the students should acquire within the chemistry course at the lower secondary school (Nuffield Science Teaching Project, 1972). Therefore, particular attention was paid within the analysis to specific aspects of the textbook content that may help towards the shaping of the skill or acquiring and processing information contained in the periodic table of chemical elements.

It should be stressed here, however, that a mere presence in the textbooks of contents presented as the periodic table does not necessarily lead to better educational achievements of students using such textbooks. The periodic table is in fact just a tool that may yield good results if used appropriately by the student working under the teacher's supervision.

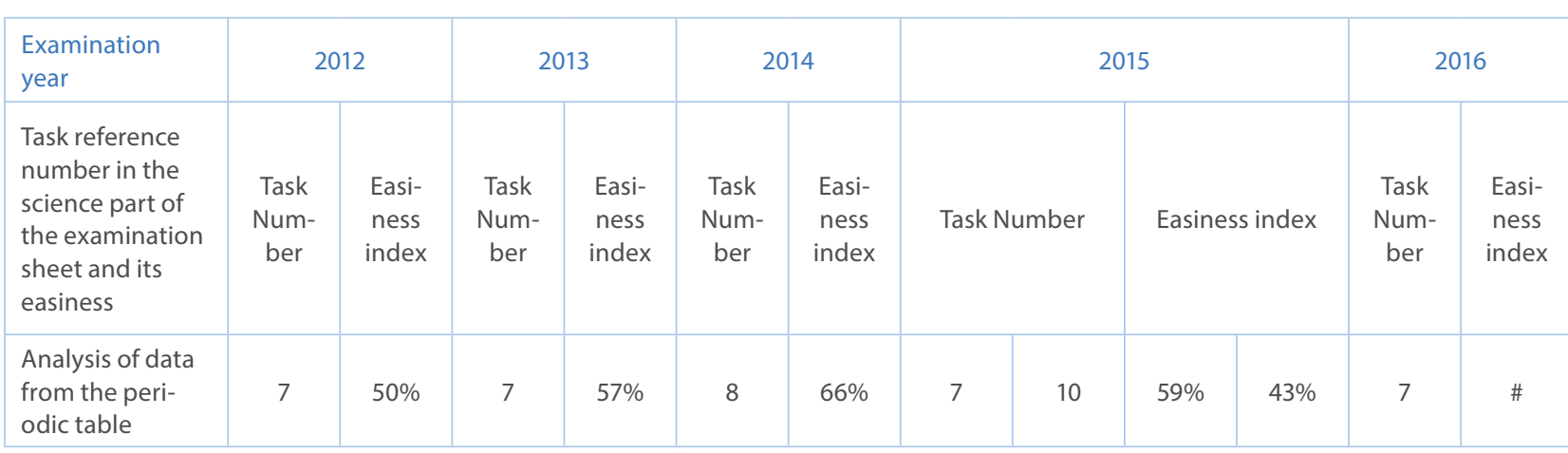

Table 1. Results of selected chemistry tasks included in the lower secondary school leaving examination based on the new formula

Source: http://www.cke.edu.pl/index.php/egzamin-gimnazjalny-left/informacje-o-wynikach

Legend: ,-"-- the sheet contained no chemistry task measuring the skill of analysis of data presented in the form of graphs; "\#" - the students' results were not yet known during preparation of the publication.

How do students cope with acquiring and processing of information (including specifically information contained in the periodic table)? Some conclusions in this regard can be drawn from their lower secondary school leaving examination results. The examination verifies the knowledge and skills acquired by the student. The results achieved by students after introduction of the new core curriculum in chemistry tasks measuring the ability to analyse data presented as graphs or tables are disappointing. According to the task easiness index assumed by the Central Examination Commission CKE (Jakubowski and Pokropek, 2009), the tasks are difficult or moderately difficult for the students (CKE, 2015; IBE, 2012; IBE, 2013). Table 1 presents the task solution rate (easiness index) of tasks included in the lower secondary school leaving examination based on the new formula and testing the aforementioned skills. It appears that almost a half of the students encounter problems trying to solve tasks that require analysis of data obtained from the periodic table.
In view of the relatively high difficulty of tasks measuring the skill of analysis and interpretation of various source data, and of the fact that textbooks are the teaching aid that is most often used by teachers (Musialik, Ostrowska, Poziomek, 2014), the following working hypothesis was formulated: the chemistry textbooks for the 3rd level of education insufficiently shape the skills of acquiring and analyzing data from various sources such as tables and graphs, and specifically - the periodic table of chemical elements.

\section{Purpose of the project}

Chemistry textbooks for the 3rd level of education were analyzed from the viewpoint of their specific presentation of the core curriculum's first objective of education. In particular, the analysis aimed at answering the following questions: 


\begin{tabular}{|c|c|c|c|c|c|c|}
\hline No. & $\begin{array}{l}\text { Series } \\
\text { No. }\end{array}$ & Series title & $\begin{array}{l}\text { Item } \\
\text { within } \\
\text { series }\end{array}$ & Textbook title & Textbook author & Publisher \\
\hline \multirow{3}{*}{1} & 1.1 & Ciekawa chemia [Interesting Chemistry] & $1 / 3$ & $\begin{array}{l}\text { Podręcznik gimnazjalisty. Part 1. Lower Secondary School } \\
\text { Student Textbook] }\end{array}$ & Hanna Gulińska, Janina Smolińska & $\begin{array}{l}\text { Wydawnictwa Sz- } \\
\text { kolne i Pedagogiczne } \\
\text { Sp. z o.o. (WSiP) }\end{array}$ \\
\hline & 1.2 & Ciekawa chemia [Interesting Chemistry] & $2 / 3$ & $\begin{array}{l}\text { Podręcznik gimnazjalisty Part 2. Lower Secondary School } \\
\text { Student Textbook] }\end{array}$ & Hanna Gulińska, Janina Smolińska & $\begin{array}{l}\text { Wydawnictwa Sz- } \\
\text { kolne i Pedagogiczne } \\
\text { Sp. z o.o. }\end{array}$ \\
\hline & 1.3 & Ciekawa chemia [Interesting Chemistry] & $3 / 3$ & $\begin{array}{l}\text { Podręcznik gimnazjalisty Part 3. Lower Secondary School } \\
\text { Student Textbook] }\end{array}$ & Hanna Gulińska, Janina Smolińska & WSiP \\
\hline \multirow{3}{*}{2} & 2.1 & $\begin{array}{l}\text { Chemia. Podręcznik dla gimnazjum [Chemistry. } \\
\text { Lower Secondary School Textbook] }\end{array}$ & $1 / 3$ & $\begin{array}{l}\text { Chemia 1. Podręcznik dla gimnazjum [Chemistry 1. Lower } \\
\text { Secondary School Textbook] }\end{array}$ & Maria Barbara Szczepaniak, Janina Waszczuk & WSiP \\
\hline & 2.2 & $\begin{array}{l}\text { Chemia. Podręcznik dla gimnazjum [Chemistry. } \\
\text { Lower Secondary School Textbook] }\end{array}$ & $2 / 3$ & $\begin{array}{l}\text { Chemia 2. Podręcznik dla gimnazjum [Chemistry 1. Lower } \\
\text { Secondary School Textbook] }\end{array}$ & Maria Barbara Szczepaniak, Janina Waszczuk & WSiP \\
\hline & 2.3 & $\begin{array}{l}\text { Chemia. Podręcznik dla gimnazjum [Chemistry. } \\
\text { Lower Secondary School Textbook] }\end{array}$ & $3 / 3$ & $\begin{array}{l}\text { Chemia 3. Podręcznik dla gimnazjum [Chemistry 1. Lower } \\
\text { Secondary School Textbook] }\end{array}$ & Maria Barbara Szczepaniak, Janina Waszczuk & WSiP \\
\hline \multirow{3}{*}{3} & 3.1 & Chemia Nowej Ery [Chemistry for the New Age] & $1 / 3$ & $\begin{array}{l}\text { Chemistry for the New Age. Chemistry 1. Lower Secondary } \\
\text { School Textbook }\end{array}$ & Jan Kulawik, Teresa Kulawik, Maria Litwin & $\begin{array}{l}\text { Nowa Era Spółka } \\
\text { z o.o. }\end{array}$ \\
\hline & 3.2 & Chemia Nowej Ery [Chemistry for the New Age] & $2 / 3$ & $\begin{array}{l}\text { Chemistry for the New Age. Chemistry 2. Lower Secondary } \\
\text { School Textbook }\end{array}$ & Jan Kulawik, Teresa Kulawik, Maria Litwin & $\begin{array}{l}\text { Nowa Era Spółka } \\
\text { z o.o. }\end{array}$ \\
\hline & 3.3 & Chemia Nowej Ery [Chemistry for the New Age] & $3 / 3$ & $\begin{array}{l}\text { Chemistry for the New Age. Chemistry 3. Lower Secondary } \\
\text { School Textbook }\end{array}$ & Jan Kulawik, Teresa Kulawik, Maria Litwin & $\begin{array}{l}\text { Nowa Era Spółka } \\
\text { z o.o. }\end{array}$ \\
\hline \multirow{3}{*}{4} & 4.1 & $\begin{array}{l}\text { Chemia dla gimnazjalistów [Chemistry for Lower } \\
\text { Secondary School Students] }\end{array}$ & $1 / 3$ & Podręcznik. [Textbook] & Krzysztof M. Pazdro, Maria Torbicka & $\begin{array}{l}\text { Oficyna Edukacyjna } \\
\text { Krzysztof Pazdro Sp. } \\
\text { z o.o. (K. Pazdro) }\end{array}$ \\
\hline & 4.2 & $\begin{array}{l}\text { Chemia dla gimnazjalistów [Chemistry for Lower } \\
\text { Secondary School Students] }\end{array}$ & $2 / 3$ & Podręcznik. [Textbook & Krzysztof M. Pazdro, Maria Torbicka & K. Pazdro \\
\hline & 4.3 & $\begin{array}{l}\text { Chemia dla gimnazjalistów [Chemistry for Lower } \\
\text { Secondary School Students] }\end{array}$ & $3 / 3$ & Podręcznik. [Textbook & Krzysztof M. Pazdro, Maria Torbicka & K. Pazdro \\
\hline \multirow{3}{*}{5} & 5.1 & Świat chemii [The World of Chemistry] & $1 / 3$ & $\begin{array}{l}\text { Podręcznik dla uczniów gimnazjum [Lower Secondary School } \\
\text { Student Textbook..Part 1.] }\end{array}$ & Anny Warchoł (red.) & $\begin{array}{l}\text { Wydawnictwo } \\
\text { "ZamKor" P. Sagnow- } \\
\text { ski i Wspólnicy Sp. j. } \\
\text { S.K.A. (ZamKor) }\end{array}$ \\
\hline & 5.2 & Świat chemii [The World of Chemistry & $2 / 3$ & $\begin{array}{l}\text { Podręcznik dla uczniów gimnazjum [Lower Secondary School } \\
\text { Student Textbook. Part 2.] }\end{array}$ & Anny Warchoł (red.) & ZamKor \\
\hline & 5.3 & Świat chemii [The World of Chemistry & $3 / 3$ & $\begin{array}{l}\text { Podręcznik dla uczniów gimnazjum [Lower Secondary School } \\
\text { Student Textbook.Part 3.] }\end{array}$ & Anny Warchoł (red.) & ZamKor \\
\hline 6 & 6.1 & $\begin{array}{l}\text { Chemia w gimnazjum. [Chemistry - Lower Sec- } \\
\text { ondary School Course] }\end{array}$ & $1 / 1$ & Chemistry - Lower Secondary School Course & $\begin{array}{l}\text { Zofia Kluz, Krystyna Łopata, Ewa Odrowąż, } \\
\text { Michał M. Poźniczek }\end{array}$ & WSiP \\
\hline
\end{tabular}

Table 2. List of textbooks analyzed within the study 


\begin{tabular}{|c|c|c|c|c|c|c|}
\hline No. & $\begin{array}{l}\text { Series } \\
\text { No. }\end{array}$ & Series title & $\begin{array}{l}\text { Item } \\
\text { within } \\
\text { series }\end{array}$ & Textbook title & Textbook author & Publisher \\
\hline \multirow{4}{*}{7} & 7.1 & $\begin{array}{l}\text { Chemia dla gimnazjum [Chemistry for Lower } \\
\text { Secondary School] }\end{array}$ & $1 / 4$ & $\begin{array}{l}\text { Chemia. Podręcznik dla gimnazjum, część } 1 \\
\text { Chemistr. Lower Secondary School. Textbook. Part } 1 .\end{array}$ & Bożena Kałuża, Andrzej Reych & $\begin{array}{l}\text { Wydawnictwo Eduka- } \\
\text { cyjne "Żak" sp. z o.o. } \\
\text { sp. k. (Żak) }\end{array}$ \\
\hline & 7.2 & $\begin{array}{l}\text { Chemia dla gimnazjum [Chemistry for Lower } \\
\text { Secondary School] }\end{array}$ & $2 / 4$ & $\begin{array}{l}\text { Chemia. Podręcznik dla gimnazjum, część } 1 \\
\text { Chemistr. Lower Secondary School. Textbook. Part } 2 .\end{array}$ & Bożena Kałuża, Andrzej Reych & Żak \\
\hline & 7.3 & $\begin{array}{l}\text { Chemia dla gimnazjum [Chemistry for Lower } \\
\text { Secondary School] }\end{array}$ & $3 / 4$ & $\begin{array}{l}\text { Chemia. Podręcznik dla gimnazjum, część } 1 \\
\text { Chemistr. Lower Secondary School. Textbook. Part } 3 .\end{array}$ & Bożena Kałuża, Andrzej Reych & Żak \\
\hline & 7.4 & $\begin{array}{l}\text { Chemia dla gimnazjum [Chemistry for Lower } \\
\text { Secondary School] }\end{array}$ & $4 / 4$ & $\begin{array}{l}\text { Chemia. Podręcznik dla gimnazjum, część } 1 \\
\text { Chemistr. Lower Secondary School. Textbook. Part } 4 .\end{array}$ & Bożena Kałuża, Andrzej Reych & Żak \\
\hline \multirow{2}{*}{8} & 8.1 & Moja chemia [My Chemistry] & $1 / 2$ & $\begin{array}{l}\text { Moja chemia dla gimnazjum. [My Chemistry for Lower Second- } \\
\text { ary School.] }\end{array}$ & Małgorzata Nodzyńska, Jan Rajmund Paśko & Żak \\
\hline & 8.2 & Moja chemia [My Chemistry] & $2 / 2$ & $\begin{array}{l}\text { Moja chemia dla gimnazjum. [My Chemistry for Lower Second- } \\
\text { ary School.] }\end{array}$ & Jan Rajmund Paśko, Małgorzata Nodzyńska & Żak \\
\hline
\end{tabular}

Table 2. List of textbooks analyzed within the study

- Can the textbook contents help towards effective shaping of the skill of using information contained in the periodic table of elements?

- Do the textbooks offer instructions on how to use the data presented in the periodic table?

- What solutions have the textbook authors adopted to prepare students to efficiently read information contained in the periodic table?

\section{Methodology}

Analyzed have been all chemistry textbooks for lower secondary schools admitted to school use by the Ministry of National Education. Further on in this study, series numbers stated in Table 2 are used.

Left out from the analysis have been educational underpinnings included in almost all textbook series analyzed. The reason is that only the contents of textbooks are subject to mandatory review and approval by MEN, and thus certified as compliant with the core curricu- lum. Such procedures do not apply to exercise books, task books, materials on CDs attached to the textbooks, and materials for teachers.

Analyzed have been contents relating to the periodic table of chemical elements included in the core curriculum for chemistry within the 3rd level of education and in chemistry textbooks for lower secondary schools. The following elements of the textbook contents have been analyzed:

- position of the periodic table in the textbook (within a chapter, at the end of the textbook, as an insert added to the textbook);

- compliance of information about the periodic table contained in the textbooks with the core chemistry curriculum requirements;

- inclusion in the textbook of a description of the way of reading data contained in the periodic table;

- the color scheme of periodic tables of elements.

It should be stressed that the analysis aimed not at comprehensive assessment of the textbooks but rather of their selected elements potentially influencing the shaping of the students' competences.

\section{Findings}

4.1. The periodic table in the detailed requirements of the core chemistry curriculum for lower secondary schools

The structure of the periodic table and the ability to read the information it contains are described in the core curriculum for the 3 rd level of education as five detailed requirements: $2.1 ; 2.3 ; 2.4 ; 2.12$ and 4.2 . The skills should be developed at the extended 4 th level of education (the description is contained mainly in chapters 2 and 3 and in subsection 8.1), and then tested within the secondary school final examination, as since 2015, the tasks contained in the final examination sheet may refer also to requirements for lower levels, e.g. the 3 rd level of education (lower secondary school). 


\subsection{Position of the periodic table in the textbook}

The periodic table of chemical elements is a table for frequent use by the student, hence the optimum solution is to add that table to each volume of the series. It also seems a good solution to choose a position where the table would be easy to find quickly. The position and number of periodic tables contained in each volume of the series under analysis is shown in Table 3.

The authors of most of the series added the periodic table to each part of the textbook. The exceptions include series 7 and 8, where periodic tables are only found in some of the textbooks. The textbooks of some series contain 2 or 3 periodic tables each, presenting different chemical elements data. In most cases, the periodic table was a fixed insert or was positioned on the inside cover. An interesting solution is a moving periodic table attached as an insert to the textbook. Such solution was chosen by Publisher 4. All authors added the modern long version of the periodic table, as recommended by the International Union of Pure and Applied Chemistry (IUPAC).

4.3. Compliance with the core curriculum's provisions pertaining to the periodic table

Under the teaching content for chemistry within the 3rd level of education, the core curriculum provides that upon completion of the lower secondary school course in chemistry, the student should be able to perform the following activities based on the periodic table of elements:

- read (...) the basic information about elements (symbol, name, atomic number, atomic mass, element type - metal or non-metal),

- determine the number of protons, electrons and neutrons in the element's atom (...),

\begin{tabular}{|c|c|c|c|}
\hline $\begin{array}{l}\text { Se- } \\
\text { ries } \\
\text { no. }\end{array}$ & $\begin{array}{l}\text { Item } \\
\text { within } \\
\text { series }\end{array}$ & $\begin{array}{c}\text { Number of } \\
\text { periodic } \\
\text { tables }\end{array}$ & Position in the textbook \\
\hline \multirow{3}{*}{1} & $1 / 3$ & 2 & insert \\
\hline & $2 / 3$ & 2 & insert \\
\hline & $3 / 3$ & 2 & insert \\
\hline \multirow{3}{*}{2} & $1 / 3$ & 2 & insert \\
\hline & $2 / 3$ & 2 & insert \\
\hline & $3 / 3$ & 2 & insert \\
\hline \multirow{3}{*}{3} & $1 / 3$ & 3 & insert \\
\hline & $2 / 3$ & 2 & insert \\
\hline & $3 / 3$ & 2 & insert \\
\hline \multirow{3}{*}{4} & $1 / 3$ & 3 & Inside cover and moving table \\
\hline & $2 / 3$ & 3 & Inside cover and moving table \\
\hline & $3 / 3$ & 3 & Inside cover and moving table \\
\hline \multirow{3}{*}{5} & $1 / 3$ & 2 & insert \\
\hline & $2 / 3$ & 2 & insert \\
\hline & $3 / 3$ & 2 & insert \\
\hline 6 & $1 / 1$ & 2 & insert \\
\hline \multirow{4}{*}{7} & $1 / 4$ & 1 & Inside cover and moving table \\
\hline & $2 / 4$ & 0 & - \\
\hline & $3 / 4$ & 0 & - \\
\hline & $4 / 4$ & 1 & Inside cover and moving table \\
\hline \multirow{2}{*}{8} & $1 / 2$ & 1 & Inside cover and moving table \\
\hline & $2 / 2$ & 0 & - \\
\hline
\end{tabular}

Table 3. The position of periodic tables and their number in individual volumes of the series under analysis

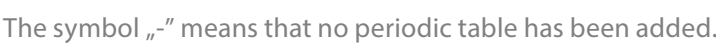

- explain the relationship between similarity of the properties of elements classified in the same group of the periodic table and the structure of atoms and number of valence electrons,
- (...) read the maximum valence for elements from groups: 1., 2., 13., 14., 15., 16. and 17. (in relation to oxygen and hydrogen),

- (...) read the basic information about nitrogen, oxygen and hydrogen (...).

Table 4 presents information about the periodic table of chemical elements contained in individual textbook series and their compliance with the requirements of the core chemistry curriculum for the 3rd level of education.

\subsection{The variety of information included in periodic tables}

Within the obligatory course, the students only encounter the periodic table of chemical elements at the lower secondary school level. It seems, therefore, that the periodic tables inserted in textbooks should contain mainly information about the basic properties of the elements, such as: the chemical symbol, name, atomic and mass number, as well as the markings of group numbers and periods. Table 5 summarizes all element data contained in the periodic tables added to individual textbook series.

Each textbook series contained at least one periodic table stating the basic element information (symbol, name, atomic number and group \& period number). The exceptions include periodic tables in series 2, where period numbers and element names are missing, and in series 3 and 5, where only the elements' symbols are stated but the names are missing. From one of the periodic tables of series 2 , the atomic number is also missing. Not all of the periodic tables state the atomic masses of the elements, but each publisher added at least one table containing that information to its textbook. The division of elements into metals and nonmetals was present in at least one textbook of each series. Additionally, the authors of series 4, 7 and 8 distinguished semimetals. On the other hand, the authors of series 2 divided 


\begin{tabular}{|c|c|c|c|c|c|c|c|c|}
\hline \multirow{2}{*}{ Core curriculum chapters and contents } & \multicolumn{8}{|c|}{ Series no. } \\
\hline & 1 & 2 & 3 & 4 & 5 & 6 & 7 & 8 \\
\hline \multicolumn{9}{|l|}{ Chapter 2. Inner structure of the matter } \\
\hline \multicolumn{9}{|l|}{2.1 reads basic element information from the periodic table } \\
\hline - chemical symbol, & + & + & + & + & + & + & + & + \\
\hline - name, & + & + & + & + & + & + & + & + \\
\hline - atomic number, & + & + & + & + & + & + & + & + \\
\hline - atomic mass, & + & + & + & + & + & + & + & + \\
\hline - element metallicity (metal or nonmetal) & + & + & + & + & + & + & + & + \\
\hline $\begin{array}{l}\text { 2.4. explains the relationship between similarity of the properties of elements } \\
\text { classified in the same group of the periodic table and the structure of atoms and } \\
\text { number of valence electrons; }\end{array}$ & $\mathrm{R}$ & $\mathrm{R}$ & $\mathrm{R}$ & $\mathrm{R}$ & $\mathrm{R}$ & z & $\mathrm{R}$ & Z \\
\hline \multicolumn{9}{|l|}{$\begin{array}{l}2.12(. . .) \text { reads from the periodic table the maximum valence for elements of } \\
\text { groups: } 1 ., 2 ., 13 ., 14 ., 15 ., 16 \text {. and } 17 \text { : }\end{array}$} \\
\hline - in relation to hydrogen, & 1 & $\mathrm{R}$ & I & 1 & $\mathrm{R}$ & Z & $\mathrm{R}$ & $\mathrm{R}$ \\
\hline - in relation to oxygen. & I & R & I & I & $\mathrm{R}$ & Z & $\mathrm{R}$ & $\mathrm{R}$ \\
\hline \multicolumn{9}{|l|}{ Chapter 4. Air and other gases } \\
\hline $\begin{array}{l}4.2(. .) \text { reads from the periodic table of elements and from other sources of } \\
\text { knowledge information about } \\
\text { - nitrogen, } \\
\text { - oxygen, } \\
\text { - hydrogen; (...); }\end{array}$ & $\begin{array}{l}Z \\
Z \\
Z\end{array}$ & $\begin{array}{l}Z \\
Z \\
Z\end{array}$ & $\begin{array}{l}\mathrm{N} \\
\mathrm{N} \\
\mathrm{N}\end{array}$ & $\begin{array}{l}\mathrm{N} \\
\mathrm{N} \\
\mathrm{N}\end{array}$ & $\begin{array}{l}\mathrm{N} \\
\mathrm{N} \\
\mathrm{N}\end{array}$ & $\begin{array}{l}\mathrm{N} \\
\mathrm{N} \\
\mathrm{N}\end{array}$ & $\begin{array}{l}\mathrm{R} \\
\mathrm{R} \\
\mathrm{Z}\end{array}$ & $\begin{array}{l}\mathrm{N} \\
\mathrm{N} \\
\mathrm{N}\end{array}$ \\
\hline
\end{tabular}

Table 4. Consistency of information about the periodic table contained in the analyzed textbooks with the core chemistry curriculum requirements for the lower secondary school

Legend: $\mathrm{R}$ - the description of the requirement is extended (with examples); $\mathrm{Z}$ - the description of the requirement is concise (general trend); $\mathrm{N}$ - no description of the requirement; $\mathrm{I}$ - other conception has been used for the requirement; ${ }{ }^{\prime \prime}$ - the description of the requirement has been provided.

elements into metals and nonmetals and distinguished noble gases among the nonmetals.

The properties of chemical elements, their ions and compounds are a periodic function of their atomic number, which is why the periodic table is the proper place to present changes in properties of elements from one and the same group or period. In point 2.4 , the core curriculum provides that the student should be able to explain the relationship between similarity of the proper- ties of elements classified in the same group of the periodic table and the structure of atoms and number of valence electrons. Three publishers provided information about changes of physical properties in at least one of their periodic tables. Publisher 1 noted the state of aggregation of the elements, publisher 3 - the melting and boiling points, and publisher 5 - the density. All data have been presented in units known to the students from the lower secondary school physics course.
The analyzed periodic tables devote little space to information about atomic structure, as e.g.:

- number of electrons in shells - only series 4,

- atomic radius - series 2 and 4 (required at the extended $4^{\text {th }}$ level of education),

- ionic radius - series 2 (required at the extended $4^{\text {th }}$ level of education),

The authors of series 2 provide a graphic illustration of the length of the elements' atomic and ionic radius together with the relevant numerical values. This way, the student can immediately notice the atomic and ionic radius length trends in individual groups and periods of the periodic table.

The skill of reading from the periodic table the maximum valence for elements of groups: 1., 2., 13., 14., 15., 16. and 17. (in relation to oxygen and hydrogen), described in point 2.12 of the core chemistry curriculum for the 3rd level of education, is required for determination of the molecular and structural formulas of chemical compounds further on within the chemistry course. The students should be able to read that information from the periodic table even if not stated directly. However, the authors of series 1 and 5 textbooks stated the valences of elements directly in the periodic table.

A form of presentation of information that is potentially interesting for the students is addition of photographs or drawings illustrating the elements. The photographs of elements can be found in three textbook series. Stated on the photographs is such information as e.g.: element samples, portraits of their discoverers or the year of discovery (series 5), as well as applications of the elements (series 6). Other additional information provided in the periodic tables included e.g. determination of noble gases (series 2 and 3), trace elements (series 6) and artificially obtained elements (series 3 and 6).Besides, several publishes also quoted the year of discovery of the element in the periodic table (series 1, 4, 5 and 6). 


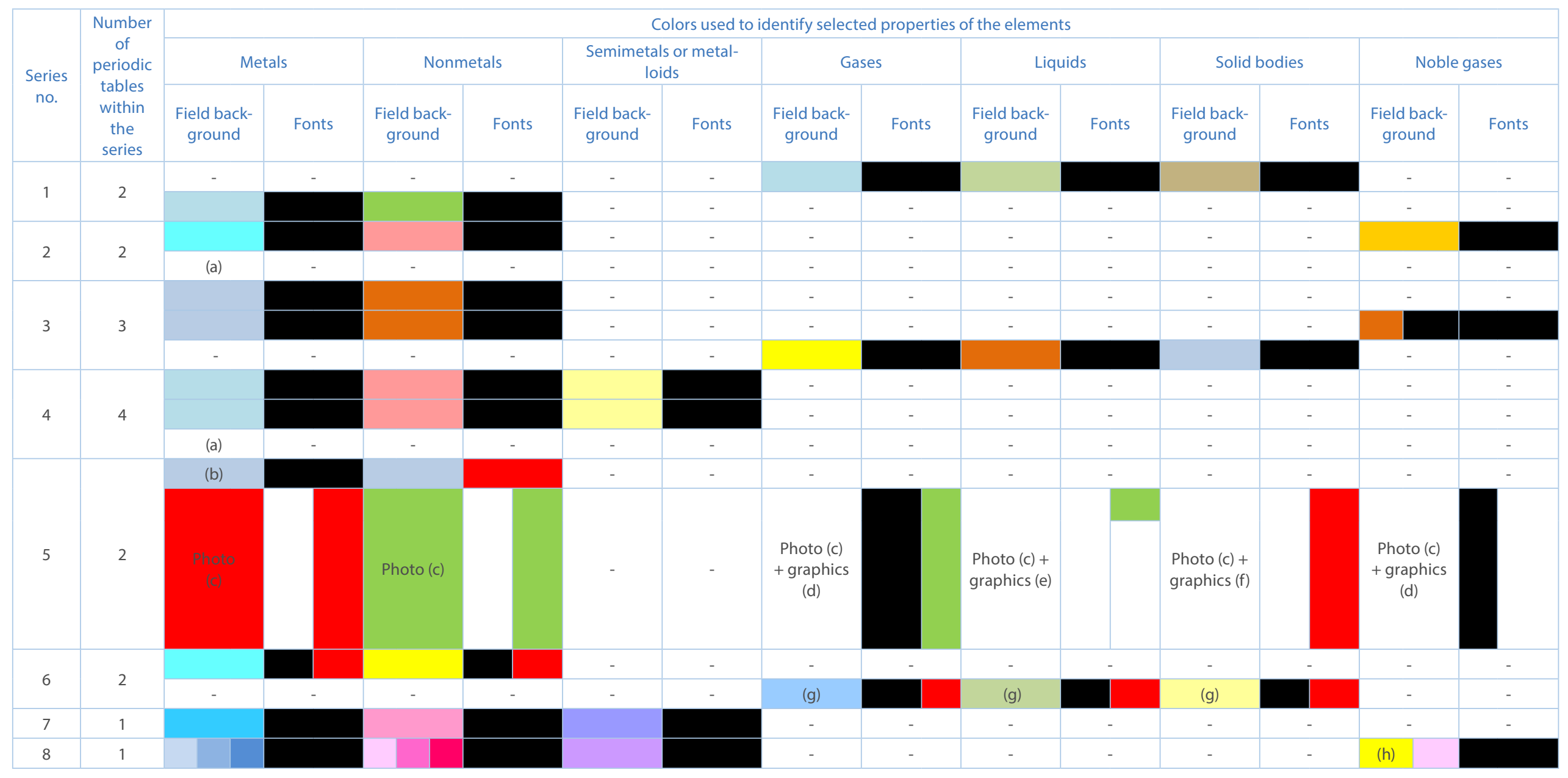

Table 6. Colors used in periodic tables to identify selected properties of the elements

Where:

$a$ - Periodic table showing atomic and/or ionic radii of a number of chemical elements; $b$ - Lanthanides and actinides shown against a violet background in the textbook series;

$c$ - background photograph added; $d$-illustration showing green fog; $e$-illustration showing a bar with a droplet pattern; $f$-illustration showing a uniform bar;

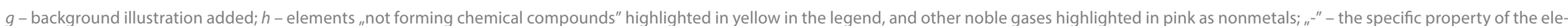
ments was not distinguished. 


\subsection{Coloring of the periodic table}

Table 6 presents colors used in the analyzed textbook series to distinguish the properties of chemical elements in periodic tables. Also the font and element field background colors within the periodic table were considered.

Almost all authors of the analyzed textbook series used background color for fields of the periodic table to illustrate the elements' chemical character. Metals were most often highlighted in blue (all textbook series except the second table within series 5), and nonmetals - in pink (series 2, 4, 7 and 8), orange (series 3), green (series 1 and 5) or yellow (series 6). Red was also used to highlights nonmetals within series 5 , but the authors of that textbook provided red symbols and names of nonmetal elements instead of using the red background. On the other hand, the first periodic table within series 6 used red for the symbols of all chemical elements, thus reducing the information value derived from the use of a vivid color. Further, semimetals were shown against a violet (series 7 and 8 ) or yellow background (series 4). In most cases, the font color strongly contrasted the table field color.

The authors of three textbook series also used colors to identify the state of aggregation of the elements in the periodic table. Thus series 1 and 6 used blue and series 3 - yellow as the background color for elements in the gaseous state. Liquids were identified with a green (series 1 and 6) or orange background (series 3), while beige (series 1), blue (series 3 ) and yellow (series 6) was used as the background color for solid bodies. The prevalent font color was black, but some authors also used red (series 5 and 6), green and white (series 5). It is only natural that the publishers refrained from experimenting in this respect as black offers the best contrast against a colorful background.

\section{Discussion of the findings and conclusions}

Mastering of the technique of seeking relevant information needed to solve a problem at the earliest possible level of education is most valuable, and students should be encouraged accordingly as often as possible (Nuffield Science Teaching Project, 1972). The periodic table of chemical elements is among the most important sources of chemical knowledge.

Chemistry focuses on atoms, molecules, ions, electrons and other elementary entities (Burewicz and Gulińska, 1993). To become well acquainted with a phenomenon and to understand it, one has first to experience it with one of the senses. Without such direct interaction, the student lacks active inner participation (Lück, 2010) and is forced incessantly to abstract. The student goes through a sequence of abstraction levels - from sensual perception through recognition of structures and then atomic and subatomic structures to formal abstraction (understanding of symbols and formulas). Thinking and language are inseparable. Becoming acquainted with the world of chemistry with chemical symbols and conceptions as its essence, the students have to use the chemical language practically from the very start (Bogdańska-Zarembina, 1966). In the process of teaching and learning, especially of abstract contents expressed in symbolic language, an extremely important role is played by various graphic materials. Among the graphic materials that are used in chemical education, Soczewka (1988) mentions various tables. They teach students to read numerical or conceptual data, and thus to give such data a structured content (verbalization) (Soczewka, 1988). One of such tables is the periodic table of chemical elements. Periodical tables are artifacts designed so as to best arrange the basic chemical knowledge (Marchese, 2008). For the chemist, they pro- vide the departing point for consideration of the matter. They arrange the branch of knowledge and provide it with a strict framework (Ostrowska and Spalik, 2010). With time, their design underwent various changes due both to gradual supplementation of the knowledge of the elements and the chemists' perception of their organization and conception (for example, „Table des différents rapports” by Étiénne-François Geoffroy (1718); Dmitri Mendeleyev's table (1869); Charles Janet's table (1927); Bayley-Thomsen-Bohr's table; spiral table developed by Theodore Benfey (1960) (Marchese, 2008). It is hardly an exaggeration to state that the periodic table of elements is the foundation of modern chemistry from both the researcher's and the teacher's viewpoint, hence the great importance of making the student acquainted early with that source of knowledge.

Konieczna (1991) writes that the extent of utilization of the periodic table as a synthetic and rich source of information depends on the mastered regularities of the theory of constitution of the matter (...). To understand the principles of periodic classification of the elements based on their atomic structure (...) one should use it on an ongoing basis (Konieczna, 1991). It is stated in the detailed comments on implementation of the core curriculum (1. Lower secondary school - 3rd level of education) that particular attention should be paid to: (...) efficient reading of element information from the periodic table.

For the students to become proficient in the use of the periodic table, they should use that source of information as often as possible. Therefore, the good solution is to add the table to each volume within a textbook series. As follows from analysis of Table 3, the authors of all series (except those identified as 7 and 8) added the periodic table to all parts of the textbook. As follows from the findings of a questionnaire survey into 
the use of chemistry textbooks by teachers of chemistry at lower secondary schools ${ }^{1}$, carried out by the Science Subjects Laboratory of the Educational Research Institute, teachers consider the periodic table of elements to be the basic tools in the teaching of chemistry. The teachers stated that students should use the periodic table on a regular basis - within each thematic block ${ }^{2}$ and during each year of the lower secondary school level chemistry course ${ }^{3}$. This is what makes easy access to the periodic table during all chemistry classes so important. In most of the analyzed textbook series, the periodic table was fixed as an insert or positioned on the inside cover, which seems a good solution as the students can quickly find the table.

The skill of using the periodic table is mentioned directly in four detailed requirements $(2.1 ; 2.4 ; 2.12$; and 4.2), and also assumed in point I. of the general requirements. Provisions of the core curriculum have been treated literally as recommended by MEN (MEN, 2009, p. 150) - only matters mentioned specifically were identified as mandatory and taken into account when assessing compliance of presented contents with the core curriculum (Table 4). However, notions were also analyzed that were not mentioned explicitly in the core curriculum (and therefore the textbooks authors were not obliged to include them in their works), but could be found in the textbooks or the attached periodic tables

1 Interviewed was a random sample of 160 teachers of chemistry at the 3 rd level of education from 16 provinces. Unpublished data

2 The core curriculum for chemistry at the 3rd level of education includes 9 thematic blocks: Substances and their properties, Inner constitution of the matter, Chemical reactions, Air and other gases, Water and water solutions, Acids and bases, Salts, Carbon gases, Water and water solutions, Acids and bases, Salts, Carbo

3 The biggest proportion of the teachers (over 90\%) stated that students should use data from the periodic table when studying constitution of the matter, chemical reactions, the properties of salts and the properties of substances. of chemical elements ${ }^{4}$. As required by the core curriculum, textbooks (and periodical tables) should contain such information as: the element's symbol, atomic mass, division into metals and nonmetals, group number and period number. The study demonstrated compliance of the textbooks with the core curriculum in this respect (the exception was the reading of information about oxygen, nitrogen and hydrogen). The authors of all series included in their textbooks both the basic information about the periodic table's structure, and information about the elements as such, e.g. about their atomic numbers and masses. The contents of all textbook series describe the method of reading the periodic table to find out which element is a metal or nonmetal. What is worth stressing, the most detailed descriptions contained in all textbook series dealt with the relationship between the element's atom structure and its position in the periodic table. As required by the core curriculum, attention was also paid on similarity of the properties of elements from one and the same group of the table. The reading of valence from the periodic table was discussed in the textbooks of series 2, 5, 6, 7 and 8. Series 1, 3 and 4 proposed a different way of reading the valence - the student may read it from additional tables included in the textbook. This latter approach seems less advantageous as some students may give up looking for information in the periodic table (which is more difficult) and use data shown directly in such additional tables.

The reading of nitrogen, oxygen and hydrogen information from the periodic table was not mentioned within discussion of the gases' properties in all series.

4 The commentary to the core chemistry curriculum, subsection 2 : The order of teaching individual thematic blocks and distribution of the material sang the The contents taugh do not have to be of the material states that. The contents taught do not have to be limited to those included in the core curriculum. The teacher may extend the scope of the curriculum according to specific conditions of work (talented class, increased number of hours, small student groups.).
The probable reason was that in several cases, the gases were discussed before the description of the periodic table of elements (series 3, 4 and partly 7). In series 5 and 7 , no reference was made to the periodic table when describing the properties of gases mentioned in point 4.2 of the core curriculum. It is worth stating here, however, that a student who has mastered the skill of reading, analyzing and interpreting information from the periodic table is certain to also meet the requirement of point 4.2 of the core curriculum and efficiently read basic information about nitrogen, oxygen and hydrogen.

The amounts of information provided in the periodic tables attached to the analyzed textbooks varied greatly. Summary information is presented in Table 5. Worth quoting here are the findings of a study into chemistry teachers' expectations - the data have been derived from a questionnaire survey of 160 lower secondary school chemistry teachers 5 . Most teachers argued that the tables should include first of all the information that is directly specified in the core chemistry curriculum for the 3 rd level of education. Over $90 \%$ of the 160 teachers participating in the survey stated that the periodic table should contain the following information: the element's symbol, name and atomic number, as well as division of the elements into metals and nonmetals. Besides, over $85 \%$ of the teachers wanted also group and period number added to the periodic table. Over a half of the teachers mentioned additionally the state of aggregation of the element as the information that should be added to the periodic table. Some teachers participating in the survey wanted also other data added to the tables: for example, every third teacher were for adding information about the elements' electronegativity (not included in the lower secondary school core curriculum), and somewhat less than one-fourth argued that the tables

5 Interviewed was a random sample of 160 teachers of chemistry at the 3rd level of education from 16 provinces. Unpublished data. 
should contain relevant photographs. Individual teachers stated that the following should be added to the periodic table: mass numbers of isotopes, melting and boiling points and density of the elements, as well as the oxidation states and valence. It should be stressed that some of the examined periodic tables contained a great variety of data pertaining to an individual chemical element. For example, the periodical table from series 5 included as many as 11 different data for a single element. Such accumulation of information within a single field of the table may make its analysis difficult, especially for students with dysfunctions (as e.g. vision defect, dyslexia, ADHD). It is worth stressing that in the situation of information overload, the students may experience the same problems as adults, e.g. frustration, tension, stress, fury or panic (Akin, 1998). The problem of periodic tables being overloaded with information was discussed by Osorio (Osorio, 1990), who observed that the periodic tables used today contain very big amounts of physical and chemical data. Although such data are of material practical value, they may cause an unintended limitation of the periodical table's educational aspect. What seems a good solution of the problem of information overload affecting the periodic table is inclusion in the textbooks of several tables with different data sets, including at least one containing only the information that is used most often during the course, such as the element's name, symbol, atomic mass and atomic number.

There is also another aspect of the information overload of periodic tables contained in textbooks: the excess of colorful visual stimuli. As follows from research, color is of fundamental importance for perception and serves as a strong stimulus that can either enhance or weaken the message (Zhu and Zhu, 2009). Researchers believe that colors influence cognition and behavior through evolutional predispositions and acquired asso- ciations (Elliot and Maier, 2014). In was demonstrated that color is an efficient coding tool making it possible to arrange the visible world through its grouping into similar objects, and that the use of graphics and colors has an impact on the process of memorizing thus presented information (Kuhbandner, Spitzer, Lichtenfeld, Pekrun, 2015). Besides, Kuhbandner et al. (2015) demonstrated that while color does not influence the ability to memorize an object as such, it is of big importance for memorizing the color of the object. For example, warmcolored objects, i.e. red and yellow, are memorized better than cold=colored ones, i.e. blue and (especially) green. Intense colors such as red and yellow attract the viewer's attention as they are deeply rooted in the human subconscious as the colors that signal danger (e.g. from predators). Instead, green and blue are much less effective in attracting the attention, which is due to their prevalence in the natural environment (green plants and blue sky). The human subconscious does not associate those colors with danger but rather with neutral or positive things. According to Bieck (2014), the graphic element that exerts the biggest influence on its perception is the proper choice of the color palette. What is more, a vast majority of graphics use color improperly, and thus instead of helping towards understanding, the color hinders, disturbs, overwhelms or distorts information derived from data.

The variety of colors used in the analyzed textbook series to distinguish specific properties of chemical elements in periodic tables is presented in Table 6. As follows from data obtained, colors used most often in the tables were as follows: blue (used 14 times for background or other graphic elements) and red (used 10 times). Used somewhat less often was green and yellow (7 times each) and pink (6 times). What may result from the fact that red (pink) and blue exert a specific impact on the perception of information, and that those two colors were used most often in the analyzed periodic tables? It should be stressed first of all that the context in which the colors appear greatly affects their perception (Elliot and Maier, 2012) - in the case of metals and nonmetals, the authors of periodic tables chose the "blue-pink" pair obtaining contrast, which is however less intense compared to the "blue-red" pair. Is the use of such colors to identify the element's chemical character in the periodic table beneficial for the memorizing of properties of metal/nonmetal elements? Research shows that blue is among the inferiorly memorized colors, while pink is memorized quite well (Pérez-Carpinell, Baldoví, de Fez, Castro, 1998). Both blue and pink are soothing (Bakhshi and Gilbert, 2015), and thus the student is less likely to focus on them as intensely as would be the case with red or yellow (Zhu and Zhu, 2009; Kuhbandner, Spitzer, Lichtenfeld, Pekrun, 2015). Both colors are more likely to favor conceptual work on solving specific cognitive problems related to analysis of the periodic table that the very formation of the association between the element's color-symbol (name) and property (metal-nonmetal), which is not to say that they would materially reduce the ability to memorize such pairs. It is worth stressing that the authors of series 3 of the textbooks departed from the traditional bluepink pair identifying the elements' metallicity and replaced pink with orange as identification of nonmetals. Orange is most helpful in the memorizing of contents associated with that color (Perez-Carpinell, Baldovi, de Fez, Castro, 1998), which should yield good results and induce the memorization of nonmetals. Similar advantages could be obtained by the authors of textbook series 6 who identified nonmetals with yellow. In the case of textbook series 1 and 5, instead, the students might have bigger problems memorizing nonmetals as they have been identified with a green background (Kuhbandner, Spitzer, Lichtenfeld, Pekrun, 2015). Only sev- 
eral publishers decided to include in their handbooks periodic tables stating the elements' state of aggregation (see Table 6), and in 3 cases color was used to identify only the noble gases. Prevailing colors were: red. yellow and green, whose selection seems to have had little in common with any general associations relating to the state of aggregation (e.g. in series 3, liquids were identified with orange, and solid bodies with blue). Although additional research would be required to find out which of the color combinations is actually the best one for cognitive processes, it is worth stressing that the very use of various colors in the periodic table is reasonable: as follows from extensive research, colorful objects or scenes are memorized better than their equivalents shown in the gray scale (Borges et al., 1977; Wichmann et al., 2002; Spence et al., 2006). Selecting the palette for the periodic table, one should also bear it in mind that red should be used guardedly: although it helps focus on details, it has also been demonstrated to negatively affect the learning efficiency (Gnambs, Appel, Kaspar, 2015).

Several other problems relate to the use of various colors to identify the elements' properties. First, the use of colors in the periodic table may result in emergence and then consolidation of erroneous convictions that are most difficult to eradicate later on in the teaching process (Markowska et al., 2014). For example, intuitive association of blue with a cold object may make the students believe that all metals are cold-colored, which is not true (e.g. gold, copper). Besides, the students may develop an erroneous conviction or consolidate a subjective impression that metals as such are generally "cold", while in fact, due to their very good heat conduction, metals can be both very cold and very hot. What is more, the authors of almost all textbooks (except the second volume of series 5) use blue to identify metals in the period table. The situation is similar in the case of nonmetals where in five of the eight cases, various shades of pink have been used to identify that specific property. Paśko (2012) writes that although such (...) color identification does not disturb the learning process, so-called mental shortcuts can be observed: metals are blue, and nonmetals are pink. This kind of shortage prompted a student (when asked to enumerate the features of metals) to state that "metals are blue". Second, the use of the same colors to identify different properties of the elements in separate periodic tables within one textbook series will probably confuse the student Examples include the use of one and the same color (orange) as identification of nonmetals in one periodic table and of liquids and noble gases in another table in the same textbook (series 3), or the use of a blue background for both metals and nonmetals in one and the same periodic table (series 5).

A separate issue is the use of ingenuous but not too legible and thus inefficient graphics to identify the elements' state of aggregation (see Table 6 , series $5-d$, $e$ and $f$ ), which may result in a mistaken reading of the element's properties and in memorization of information that is simply false. One last issue that may cause problems for the students using the periodic tables is the use of complex graphics (e.g. photography) to identify various properties of the elements (series 5). Small graphics with a lot of detail require the students' higher concentration, and may therefore place an excessive burden on the working memory and overload the individual's cognitive resources, leading to the student's discouragement and task evasion (Łompieś, 2015). As Alvin Toffler wrote in his book „Future Shock” (1970), there are limits to the sensory stimuli that we can accept, and also to our ability to receive, process and memorize information. Humans have their limitations, and information overload seriously reduces task performance. Efficient adaptation is only possible if the amount of stimuli is neither to large nor too small. Besides, it is by no means certain that looking at a photograph of the object (element). the student will indeed memorize the exact in formation that should be memorized. Although the idea of showing the students the actual elements, whether pure or as object made of a specific element, such illustrations should not serve as the basic form of description of the element in the periodic table. Biecek (2014) writes that the influence of color may become a problem if the entire graph is dominated by a part of information coded with a color component, or if color carried no in formation and only plays the part of noise. Bearing the fact in mind that color is the strongest spice, one should dose it with moderation. Further, Tatarska (2013) argues that in a visual message, not only color but also contrast is of immense importance. Although the analyzed periodic tables generally used a strong contrast between the background and the text, contract and thus also legibility is much lower where photographs are used as the field "filler". This aspect should also be borne in mind when designing a periodic table, as the desire to add esthetic or innovative improvements may compromise clarity, which is of importance at the discussed level of abstraction.

Preparing teaching aids, one should also consider various factors that affect the students' perception of the material, as such perception depends not only on the text itself but also on its presentation (graphics, color scheme). Analysis of data collected within the study does not provide an explicit confirmation of the hypothesis stated in the introduction - that the chemistry textbooks for the $3^{\text {rd }}$ level of education insufficiently shape the skills of acquiring and analyzing data from various sources such as tables and graphs, and specifically - the periodic table of chemical elements. Despite the several problematic issues observed in the textbooks (e.g. the overloading of periodic tables with informa- 
tion, colors used in the tables to identify the elements' properties, cases of slight inconsistence of the textbook contents with the core curriculum), it has to be stressed that all authors of the analyzed textbooks added a separate chapter or topic dealing with the periodic table. Also all textbook series included at least one volume with contents that can be used to shape the skill of reading information from the periodic table.

What, therefore, is the reason of the students' relatively poor results in tasks involving the obtaining and interpretation of information from the periodic table? Some guesses can be attempted as to the origin of that phenomenon. Even before the new lower secoindary school leaving examination formula was introduced (in 2012), two students diagnoses were carried out, accompanying examinations prepared by the Central Examination Board and district examination boards ${ }^{6}$. The Lower Secondary School Student Competence Diagnosis (DKG) sheets ${ }^{7}$ included the total of four closed tasks that tested the discussed skills. In the opinion of both teachers and students, tasks relating to the periodic table were the easiest of the entire chemistry part of the lower secondary school leaving examination. This, however, was not reflected in the results of those tasks. The students results (percentages of correct answers) were as follows: task $7.1-62 \%$, task $7.2-36.7 \%$ (IBE, 2012), $7.1-44.8 \%, 7.2$ - 36.7\% (IBE, 2013). Asked about the students' relatively low scores, the teachers suggested that they probably resulted from a lack of repetition of the material before the examination. Contents relat-

6 http://eduentuzjasci.pl/badania/110-badanie/412-diagnoza-kompetencji-gimnazjalstow.html

7 During meetings dealing with DKG four secries of workshops for teachers were carried out, which included a detailed discussion of the results of the chemical part of the test. Discussed with the of the results of the chemical part of the test. Discussed with the
teachers during the meetings were e.g. the issues of difficulty of the tasks, the results achieved by those teachers' students within the diagnosis, and the methodology of work with the students on a specific problem. ing to the periodic table were usually taught in the first form of the lower secondary school, while the diagnosis took place in the third form. The teachers admitted that they not always revert to the basic issues which they treat as simple and self-evident, especially if they are not required further on within the course. This lack of regular utilization of the periodic table throughout the chemistry course at the lower secondary school is probably the problem. Therefore, irrespective of the chapter, it seems advisable that the textbooks should make regular references to the periodic table of elements, both in the textbook content and as exercises and tasks. To return to cognitive overload, it is worth stressing that it can also be advantageous if it is repeated in a regular and well-conceived manner according to the principles of so-called deliberate practice (Łompieś, 2015). Frequent overloading of the cognitive system through regular exercise, optimally repeated every day at close to the maximum intensity, contributes to development of the working memory and stimulates changes in flexibility of the brain that reflect a growth of the person's cognitive potential. According to Freinet, „genuine absorption of knowledge and development of skills occurs when we attempt to create, as this makes our knowledge operative" (Frankiewicz, 1983).

As has been stressed in the Introduction, mere presence of the relevant contests in the analyzed textbooks is not sufficient as the condition of the students' better educational achievements. The textbook as a tool may only lead to good results if used on a regular basis.

\section{Acknowledgments}

The authors wish to extend special thanks to Zbigniew Rzemieniuk for his cooperation in preparation of the working version of the study.

\section{References}

Akin L (1998). Information Overload and Children: A Survey of Texas Elementary School Students. School Library Media Research. 1: $1-16$.

Atkins PW (2005), Skeletal chemistry, What is the minimal core of an education in chemistry? Pobrano z lokalizacji: http://www.rsc. org/Education/EiC/issues/2005_Jan/skeletal.asp

Bakhshi S, Gilbert E (2015). Red, Purple and Pink: The Colors of Diffusion on Pinterest. PLoS ONE 10(2): e0117148. DOI: 10.1371/ journal.pone.0117148.

Biecek P (2014). Odkrywać! Ujawniać! Objaśniać! Zbiór esejów o sztuce prezentowania danych. Warszawa: Uniwersytet Warszawsk

Bogdańska-Zarembina A (1966). Pojęcia i symbolika chemiczna $\mathrm{w}$ procesie uczenia się. Warszawa: Państwowe Zakłady Wydawnictw Szkolnych

Borges MA, Stepnowsky MA, Holt LH (1977). Recall and recognition of words and pictures by adults and children. Bull. Psychon. Soc. 9, 113-114. DOI: 10.3758/BF03336946.

Buczek I, Musialik M, Chrzanowski MM, \& Ostrowska B (2014) Jak wprowadzić eksperyment naukowy na lekcje chemii w gimnazjum? Edukacja Biologiczna i Środowiskowa, 4: 80-83.

Burewicz A, Gulińska H (1993). Dydaktyka chemii. Poznań: Wydawnictwo Naukowe Uniwersytetu im. Adama Mickiewicza w Poznaniu.

CKE. (2015, kwiecień 15). http://www.cke.edu.pl/. Pobrano z lokalizacji http://www.cke.edu.pl/index.php/egzamin-gimnazjalnyleft/informacje-o-wynikach

Elliot AJ, Maier MA (2012). Chapter two - Color-in-Context Theory. Advances in Experimental Social Psychology, 45: 61-125.

Elliot AJ, Maier MA (2014). Color Psychology: effects of perceiving color on psychological functioning in humans. Annu. Rev. Clin. Psychol. 65: 95-120. DOI: 10.1146/annurev-psych-010213-115035.

Federowicz M, Sitek M (red) (2013). Raport o stanie edukacji 2012. Warszawa: Instytut Badań Edukacyjnych.

Frankiewicz W (1983). Technika swobodnych tekstów jako metoda kształcenia myślenia twórczego. Warszawa: WSiP.

Gnambs T, Appel M, Kaspar K (2015). The effect of the color red on encoding and retrieval of declarative knowledge. Learning and Individual Differences 42: 90-96. DOI: 10.1016/j.lindif.2015.07.017.

IBE (2012). Diagnoza kompetencji gimnazjalistów. Przedmioty przy rodnicze. Warszawa: Instytut Badań Edukacyjnych.

IBE (2013). Diagnoza Kompetencji Gimnazjalistów. Przedmioty Przyrodnicze. Warszawa: Instytut Badań Edukacyjnych.

Jakubowski M, Pokropek A (2009). Badając egzaminy. Podejście ilościowe w badaniach edukacyjnych. Warszawa: Instytut Badań Edukacyjnych.

Konieczna M (1991). Zasady dydaktyczne w kształceniu chemic- 
znym. Warszawa: Wydawnictwa Szkolne i Pedagogiczne.

Kuhbandner C, Spitzer B, Lichtenfeld S, Pekrun R (2015). Differential binding of colors to objects in memory: red and yellow stick better than blue and green. Frontiers in Psychology, 6, 231. http:// doi.org/10.3389/fpsyg.2015.00231

Lück G (2010). Chemia bez stresu, czyli co wspólnego ma ser szwajcarski z metalami. Warszawa: Instytut Wydawniczy Pax.

Łompieś JB (2015). Kognitywne konsekwencje tworzenia teksów pisanych. Lingwistyka Stosowana 15:4, 61-73.

Marchese FT (2008). The Chemical Table: An Open Dialog between Visualization and Design. 12th International Conference Information Visualisation, 75-81. DOI: 10.1109/IV.2008.79.

Markowska A, Lechowicz M, Grajkowski W, Chrzanowski MM, Spalik K, Borgensztajn J, Ostrowska EB, Musialik M (2014). Błędne przekonania w nauczaniu przedmiotów przyrodniczych, Edukacja Biologiczna i Środowiskowa. 4: 56-66.

Mehta R, Zhu RJ (2009). Blue or Red? Exploring the Effect of Color on Cognitive Task Performances. Science, 323(5918): 1226-1229. DOI: $10.1126 /$ science.1169144.

MEN (2008). Rozporządzenie Ministra Edukacji Narodowej z dnia 23 grudnia 2008 r. w sprawie podstawy programowej wychowania przedszkolnego oraz kształcenia ogólnego w poszczególnych typach szkół (Dz. U. 2009, nr 4, poz. 17). Warszawa: Ministerstwo Edukacji Narodowej.

MEN (2009). Podstawa programowa z komentarzami, T.5. Edukacja przyrodnicza w szkole podstawowej, gimnazjum i liceum; przyroda, geografia, biologia, chemia, fizyka. Warszawa: Ministerstwo Edukacji Narodowej. Pozyskano z: http://www.men.gov.pl/images/stories/pdf/Reforma/men_tom_5.pdf

MEN (2014). Rozporządzenie Ministra Edukacji Narodowej z dnia 8 lipca 2014 r. w sprawie dopuszczenia do użytku szkolnego podręczników (Dz. U. 2014, poz. 909). Warszawa: Ministerstwo Edukacji Narodowej.

Musialik M, Ostrowska B, Poziomek U (2014). Nauczyciele przedmiotów przyrodniczych. W: M. Federowicz, J. Choińska-Mika, D. Walczak (red.) Raport o stanie edukacji 2013. Liczą się nauczyciele. Warszawa: Instytut Badań Edukacyjnych.

Nuffield Science Teaching Project (1972). Chemistry. Handbook for Teachers. London: Longmans and Penguins.

Ostrowska B, Spalik K (red) (2010). Umiejętności złożone w nauczaniu historii i przedmiotów przyrodniczych. Pomiar, zadania testowe z komentarzami. Warszawa: Instytut Filozofii i Socjologii PAN.

Osorio HM (1990). A numerical periodic table and the f-series chemical elements. J. Chem. Edu., 67, 563-565.

Paśko JR (2012). Błędy w nauczaniu przedmiotów przyrodniczych, Kraków: Zakład Chemii i Dydaktyki Chemii, Uniwersytet Pedagogiczny im. Komisji Edukacji Narodowej.
Pérez-Carpinell J, Baldoví R, de Fez MD, Castro J (1998). Color Memory Matching: Time Effect and Other Factors. Color Res. Appl., 23 234-247. DOI: 10.1002/(SICI)1520-6378(199808)23:4<234::AID COL8>3.0.CO;2-P.

Pingel, F. (2009). UNESCO guidebook on textbook research and Textbook revision, United Nations Educational, Scientific and Cultural Organization, Paris. http://unesdoc.unesco.org/ images/0011/001171/117188e.pdf, 01.02.2016.

Soczewka J (1988). Metody kształcenia chemicznego. Warszawa: Wydawnictwa Szkolne i Pedagogiczne.

Spence I, Wong P, Rusan M, Rastegar N (2006). How color enhances visual memory for natural scenes. Psychol. Sci. 17: 1-6. DOI:10.1111/j.1467- 9280.2005.01656.x.

Tatarska J (2013). Rola koloru w reklamie prasowej. W: A. Wiśniewska, Frontczak, \& A, Reklama wizualna. s. 24-61. Warszawa: Wyższa Szkoła Promocji.

Toffler A (1970). Future Shock. New York: Random House, Inc.

Weiner J (2003). Technika pisania i prezentowania przyrodniczych prac naukowych. Warszawa: Wydawnictwo Naukowe PWN

Wichmann FA, Sharpe LT, Gegenfurtner KR (2002). The contributions of color to recognition memory for natural scenes. J. Exp. Psychol. Learn. Mem.Cogn.28:509-520.DOI:10.1037//0278-7393.28.3.509.

Zalecenie Parlamentu Europejskiego, D. U. (2006, 12 18). ZALECENIE PARLAMENTU EUROPEJSKIEGO I RADY. Bruksela. 